\title{
ANIMAL MANURE PHOSPHORUS CHARACTERIZATION BY SEQUENTIAL CHEMICAL FRACTIONATION, RELEASE KINETICS AND ${ }^{31}$ P-NMR ANALYSIS ${ }^{(1)}$
}

\author{
Tales Tiecher ${ }^{(2)}$, Mohsin Zafar ${ }^{(3)}$, Fábio Joel Kochem Mallmann ${ }^{(4)}$, Edson Campanhola \\ Bortoluzzi $^{(5)}$, Marcos Antonio Bender ${ }^{(6)}$, Lucas Henrique Ciotti ${ }^{(6)}$ \& Danilo Rheinheimer \\ dos $\operatorname{Santos}^{(7)}$
}

\begin{abstract}
SUMMARY
Phosphate release kinetics from manures are of global interest because sustainable plant nutrition with phosphate will be a major concern in the future. Although information on the bioavailability and chemical composition of $P$ present in manure used as fertilizer are important to understand its dynamics in the soil, such studies are still scarce. Therefore, $P$ extraction was evaluated in this study by sequential chemical fractionation, desorption with anion-cation exchange resin and ${ }^{31} \mathrm{P}$ nuclear magnetic resonance ( ${ }^{31} \mathrm{P}-\mathrm{NMR}$ ) spectroscopy to assess the $\mathrm{P}$ forms in three different dry manure types (i.e. poultry, cattle and swine manure). All three methods showed that the $P$ forms in poultry, cattle and swine dry manures are mostly inorganic and highly bioavailable. The estimated $P$ pools showed that organic and recalcitrant $P$ forms were negligible and highly dependent on the Ca:P ratio in manures. The results obtained here showed that the extraction of $P$ with these three different methods allows a better understanding and complete characterization of the $P$ pools present in the manures.
\end{abstract}

Index terms: organic amend, phosphorus bioavailability, phytate, phosphorus fractionation.

\footnotetext{
(1) Received for publication on November 18, 2013 and approved on June 9, 2014.

(2) Doctoral student in Soil Science, Universidade Federal de Santa Maria - UFSM. Av. Roraima, 1000, Bairro Camobi. CEP 97105900 Santa Maria (RS), Brazil. CAPES fellowship. E-mail: tales.t@mail.ufsm.br

(3) Doctoral student in Soil Science, UFSM. TWAS-CNPq fellowship. E-mail: mohsin_ises@yahoo.com

(4) Adjunct Professor, Faculdade Ingá - UNINGÁ. Rodovia PR 314, 6114. CEP 87035-510 Maringá (PR). E-mail: fabiojkmallmann@gmail.com

(5) Titular Professor, Faculty of Agronomy and Veterinary Medicine, Universidade de Passo Fundo. BR 285, km 292, Bairro São José. CEP 99001-970 Passo Fundo (RS), Brazil. Grant in productive supported by CNPq. E-mail: edson.bortoluzzi@pq.cnpq.br

(6) Agronomy student, UFSM. Undergraduate fellowship. E-mail: marcosantoniobender@hotmail.com, lucasciotti@hotmail.com

(7) Adjunct Professor, Soil Science Department, UFSM. Grant in productive supported by CNPq. E-mail: danilonesaf@gmail.com
} 


\title{
RESUMO: CARACTERIZAÇÃO DO FÓSFORO EM DEJETOS ANIMAIS POR FRACIONAMENTO QUÍMICO SEQUENCIAL, CINÉTICA DE LIBERAÇÃO E ANÁLISE DE ${ }^{31} P-R M N$
}

\begin{abstract}
Práticas de manejo que visam reduzir a dependência de fertilizantes inorgânicos, como o uso de dejetos animais como fonte de $P$, podem contribuir para a sustentabilidade da agricultura. Embora informações sobre a biodisponibilidade e composição química do $P$ presente nos dejetos utilizados como fertilizantes são importantes para o entendimento da sua dinâmica no solo, tais estudos ainda são escassos. Dessa forma, objetivou-se com o este trabalho avaliar o uso do fracionamento químico sequencial, da dessorção com resina de troca e da espectroscopia de ressonância magnética nuclear $\left({ }^{31} \mathrm{P}\right.$-NMR) para caracterizar as formas de $P$ presentes em três diferentes dejetos animais (ave, suíno e bovino). O fracionamento químico sequencial do $P$, a extração sucessiva com resina e a espectroscopia de ${ }^{31} P$ - $R M N$ demonstraram que as formas de P presentes nos dejetos de aves, bovinos e suínos são principalmente inorgânicas e altamente biodisponíveis. $O$ teor de $P$ orgânico e recalcitrante foi desprezível e altamente dependente da relação Ca:P nos dejetos. Os resultados deste trabalho demonstram que o uso dos três diferentes métodos, quando aplicados conjuntamente, permite a caracterização completa do $P$ presente nos dejetos animais.
\end{abstract}

Termos de indexação: adubação orgânica, biodisponibilidade de fósforo, fitato, fracionamento de fósforo.

\section{INTRODUCTION}

Phosphorus is a critically essential nutrient in natural ecosystems and also regulates global agricultural production (Cordell et al., 2009; Shen et al., 2011), however, soils in most areas of the world are $\mathrm{P}$ deficient and limit agricultural yields (King et al., 2012). This deficiency is often met by adding external $P$ to soil in various sources thereby increasing the soil $\mathrm{P}$ status. This mode of $\mathrm{P}$ application to soil have posed a serious threat to several waterways around the world resulting in an alarming increase in rate of eutrophication (Nash et al., 2007), and nourishing of algal blooms. This boosted algal biomass production has created undesirable impacts on marine biota, livestock and human health (McDowell et al., 2003).

Another growing concern in recent $\mathrm{P}$ research and management is $\mathrm{P}$ scarcity, which has gained increased attention on the research and policy agenda over recent years, partially due to the $800 \%$ price hike in phosphate rock in 2008 (Cordell et al., 2009; Gilbert, 2009). However, actual estimates of phosphate depletion or peak $\mathrm{P}$ vary widely, from the occurrence of a critical point in 30-40 to 300-400 years. Growing consciousness about P scarcity and security, coupled with the environmental impact of $\mathrm{P}$ pollution has stimulated research exploring how $\mathrm{P}$ is used and lost in the agro-ecosystem (Cordell et al., 2011; Dawson \& Hilton, 2011).

From the statistics of world P fertilizer consumption in 2011, Brazil total phosphate consumption was 3859.5 thousand tons (IFA, 2013). The global forecast of rock phosphate scarcity may lead to shortage of mineral $\mathrm{P}$ in the coming decades (Cordell et al., 2009), therefore use of manures as alternative to mineral $\mathrm{P}$ fertilizer is becoming an increasingly essential practice to decrease the demand of mineral $\mathrm{P}$ fertilizers for agriculture in Southern Brazil. On the other hand, among various nonpoint $\mathrm{P}$ pollution sources by agriculture, the over application of manures relative to typical crop needs particularly in geographical regions where animal production is concentrated and excessive manure quantities are produced is another serious challenge (Toor et al., 2004). Excessive application of manure $P$ to soils in the long term often increases the $\mathrm{P}$ transfer to soil and/or surface water (Sharpley et al., 2004). From the last decade, due to increased meat and dairy demands, the Brazilian livestock industry has expanded quickly to around $1740.7 \times 10^{6}$ animals in Brazil (IBGE, 2010). This increase in animal population will further increase by $40 \%$ from the current values over the next decade until 2021/22 and $4106.6 \times 10^{3} \mathrm{Mg} \mathrm{yr}^{-1}$ of $\mathrm{P}$ is being added to the environment (Table 1).

Most studies carried out on animal manure as fertilizer have focused primarily on the $\mathrm{P}$ availability and its forms in soil after manure application (Halajnia et al., 2009; Azeez \& Averbeke, 2010; Guardini et al., 2012; Shafqat \& Pierzynski, 2013). Although information on the bioavailability and chemical composition of $\mathrm{P}$ present in manure used as fertilizer are important for understanding its dynamics in the soil, such studies for Brazil are not yet available. In the current fertilization plans, manure application is typically based on total $\mathrm{P}$ concentration in the manure because the overall goal is to calculate and equalize the amount of manure $\mathrm{P}$ added relative to the crop needs. However, total P quantification provides no information about $\mathrm{P}$ chemical forms present in manures and their cycling in soil as well as their subsequent availability to plants. 
Table 1. The estimated increase from $2011 / 12$ to $2021 / 22$ in meat production; livestock and poultry population and phosphorus excretion in Brazil and Rio Grande do Sul

\begin{tabular}{|c|c|c|c|c|}
\hline Variable & Poultry & Cattle & Swine & Total \\
\hline \multicolumn{5}{|l|}{ Meat production predicted in Brazil $\left(10^{6} \mathrm{Mg}\right)$} \\
\hline $2011 / 2012$ & 13.0 & 8.9 & 3.3 & 25.1 \\
\hline $2021 / 2022$ & 20.3 & 11.8 & 4.1 & 36.2 \\
\hline Increase predicted in 10 -years period (\%) & 56.1 & 32.3 & 22.0 & 108.3 \\
\hline \multicolumn{5}{|l|}{ Number of animals ${ }^{(1)}$} \\
\hline Brazil $\left(10^{6}\right)$ & 1488.4 & 211.5 & 40.8 & 1740.7 \\
\hline Rio Grande do Sul State $\left(10^{6}\right)$ & 149.3 & 14.5 & 5.7 & 169.5 \\
\hline Rio Grande do Sul State ${ }^{(2)}(\%)$ & 10.0 & 6.8 & 13.9 & 30.5 \\
\hline Phosphorus excretion $^{(3)}$ (kg/animal/yr) & 0.15 & 17.77 & 3.03 & - \\
\hline Brazil $\left(10^{3} \mathrm{Mg} / \mathrm{yr}\right.$ of $\left.\mathrm{P}\right)$ & 223.3 & 3759.8 & 123.5 & 4106.6 \\
\hline Rio Grande do Sul State $\left(10^{3} \mathrm{Mg} / \mathrm{yr}\right.$ of $\left.\mathrm{P}\right)$ & 22.4 & 257.3 & 17.2 & 296.9 \\
\hline
\end{tabular}

The P availability from animal manures largely depends on its forms (organic or inorganic), and on the ligand to which they are bound (Leytem et al., 2002). Organic $P$ forms in animal manures are not readily available for plant uptake as they have to be mineralized into inorganic forms in the soil first. However, when animals are fed with supplemental minerals, $\mathrm{P}$ organic forms such as phytate can form stable complexes with $\mathrm{Ca}$ and other divalent and trivalent cations resulting in reduced hydrolysis of this organic form (Leytem et al., 2008a). Moreover, inorganic $\mathrm{P}$ release can be affected by $\mathrm{Ca}$ and $\mathrm{Mg}$ concentrations in the manure, where $\mathrm{Mg}$ concentration could have a detrimental effect on CaP stabilization in manure (Nair et al., 2003).

Analytical methods are available to characterize $\mathrm{P}$ forms in manures, but most of them are based on some type of chemical fractionation, such as sequential extraction with various acids or bases (Dou et al., 2000; Sharpley \& Moyer, 2000). However, these methods only separate manure total $P$ into fractions with different solubility, but cannot identify the exact organic or inorganic $\mathrm{P}$ species it contains. There has been a growing interest in the use of new analytical methods to characterize the organic and inorganic $\mathrm{P}$ species in manures and manure amended soils. The solution ${ }^{31} \mathrm{P}$ nuclear magnetic resonance ( $\left.{ }^{31} \mathrm{P}-\mathrm{NMR}\right)$ spectroscopy has been successively used to characterize organic $\mathrm{P}$ in manures to provide an insight into the dynamics and availability of manure organic $\mathrm{P}$ forms (Toor et al., 2003). However, because to the complexity, sophisticated instrumentation and relative high cost of the analysis, these techniques are not usually available in laboratories thus limiting their use on a large scale.

In this background, such kind of studies are needed to generate reliable results underlying the design and implementation of management strategies for suitable manure use in agro-ecosystems. Therefore, the methods of Chang and Jackson sequential $\mathrm{P}$ fractionation, ${ }^{31} \mathrm{P}-\mathrm{NMR}$ spectroscopy and successive desorption with anion exchange resin membrane were applied to characterize the different $\mathrm{P}$ forms in cattle, poultry and swine manures, to provide information on the bioavailability and chemical composition of $\mathrm{P}$ in these manures.

\section{MATERIAL AND METHODS}

\section{Manure collection}

Manures samples were collected from the region of Restinga Seca, in Rio Grande do Sul, in Southern Brazil. Cattle manure (CM) and swine manure (SM) were collected in dunghills while poultry manure (PM) was collected from poultry houses. Each manure sample was composed of 20 samples collected from different points in the dunghills and in the poultry house. As the aim of this study was to evaluate methods to characterize different $\mathrm{P}$ species in manure types, all the subsamples of each manure type were mixed and a homogenized representative sample was composed and dried at $50^{\circ} \mathrm{C}$. After drying each sample was sieved $(<2 \mathrm{~mm})$, and three replications were used for further analysis.

\section{Chemical characterization}

Total N, P, K, Ca, and $\mathrm{Mg}$ in all three manure samples were estimated by acid digestion at $350{ }^{\circ} \mathrm{C}$ for $2 \mathrm{~h}$ according to Tedesco et al. (1995). Total $\mathrm{P}$ was determined by Olsen \& Sommer (1982) and readings were carried out later with the molybdate-antimonyascorbic acid method of Murphy \& Riley (1962). Total organic $\mathrm{P}$ was estimated by an ignition method, based on the difference between the $\mathrm{P}$ amounts extracted with $0.5 \mathrm{~mol} \mathrm{~L}^{-1} \mathrm{H}_{2} \mathrm{SO}_{4}$ on ignited $\left(550{ }^{\circ} \mathrm{C}, 2 \mathrm{~h}\right)$ and non-ignited manure samples (Olsen \& Sommers, 
1982). Total Ca and Mg were determined with an atomic absorption spectrophotometer, total $\mathrm{K}$ with a flame photometer and total $\mathrm{N}$ by the micro-Kjeldahl method (Tedesco et al., 1995).

\section{Phosphorus fractionation}

The fractionation was performed to selectively extract discrete $\mathrm{P}$ pools with chemical extractants. The manure $\mathrm{P}$ forms were extracted by a modified fractionation scheme described by Chang \& Jackson (1957). Briefly, in each step, $1.0 \mathrm{~g}$ of manure sample and $50 \mathrm{~mL}$ of extractant (1:50 sample to extractant ratio) was filled in $60 \mathrm{~mL}$ centrifuge tubes with five replications The tubes were shaken on an end-overend shaker at $25^{\circ} \mathrm{C}$ for varying periods, according to the extractant type. Sequentially, the extracting solutions used were: $1.0 \mathrm{~mol} \mathrm{~L}^{-1} \mathrm{NH}_{4} \mathrm{Cl}$ for $30 \mathrm{~min}$; $0.5 \mathrm{~mol} \mathrm{~L}^{-1} \mathrm{NH}_{4} \mathrm{~F}$ at $\mathrm{pH} 8.2$ for $16 \mathrm{~h} ; 0.1 \mathrm{~mol} \mathrm{~L}^{-1} \mathrm{NaOH}$ for $16 \mathrm{~h}$; citrate bicarbonate dithionate (CBD) for $16 \mathrm{~h}$; and $0.25 \mathrm{~mol} \mathrm{~L}^{-1} \mathrm{H}_{2} \mathrm{SO}_{4}$ for $16 \mathrm{~h}$. After the extractions, the residual material was dried at $50{ }^{\circ} \mathrm{C}$ and the content of residual $\mathrm{P}$ was estimated by digestion of $0.5 \mathrm{~g}$ residue with $\mathrm{H}_{2} \mathrm{SO}_{4}+\mathrm{H}_{2} \mathrm{O}_{2}$ at $200{ }^{\circ} \mathrm{C}$ for $2 \mathrm{~h}$ (Olsen \& Sommers, 1982). In the alkali extract of $\mathrm{NaOH}$, total $\mathrm{P}$ was estimated by digestion with $\mathrm{H}_{2} \mathrm{SO}_{4}$ and ammonium persulphate in an autoclave at $121^{\circ} \mathrm{C}$ (USEPA, 1971), and subsequent $\mathrm{P}$ determination, according to Murphy \& Riley (1962). In the other extracts, the content of $\mathrm{P}$ was directly determined by following the Murphy \& Riley (1962) method.

\section{Phosphorus release pattern}

The $\mathrm{P}$ and Ca desorption capacity was evaluated by successive extractions with anion-cation exchange resin (ACER), $0.1 \mathrm{~g}$ of each manure sample with five replications into $60 \mathrm{~mL}$ centrifuge tubes with $50 \mathrm{~mL}$ of distilled water and one sheet of bicarbonatesaturated ACER. The suspension was shaken for $16 \mathrm{~h}$ in an end-over-end shaker at $\pm 25^{\circ} \mathrm{C}$. The resin sheets were then removed and washed with distilled water to remove the solid fractions, and washed again in $10 \mathrm{~mL}$ of $0.5 \mathrm{~mol} \mathrm{~L}^{-1} \mathrm{HCl}$ to transfer the $\mathrm{P}$ and $\mathrm{Ca}$ retained on the resin into the acid solution. The extraction was repeated 18 times consecutively, when the amount of extracted $\mathrm{P}$ and $\mathrm{Ca}$ became constant and near zero. The $\mathrm{P}$ content extracted each time was determined by the method of Murphy \& Riley (1962). Calcium was determined with an atomic absorption spectrophotometer. The cumulative values of desorbed $\mathrm{P}$ and Ca were calculated, using the first-order kinetics equation proposed by McKean \& Warren (1996) as follows:

$$
\text { Por } C a_{\text {dessorbed }}=\beta-(\beta-\alpha) e^{-\lambda t}
$$

where $\beta$ is the maximum amount of $\mathrm{P}$ or $\mathrm{Ca}$ desorbed; $\alpha$ is the amount of $\mathrm{P}$ or Ca desorbed in the first extraction (readily bioavailable portion); $\lambda$ is the desorption rate constant; and $t$ is the extraction time.

\section{${ }^{31}$ P-NMR analysis}

The ${ }^{31} \mathrm{P}-\mathrm{NMR}$ analysis was performed with five $0.5 \mathrm{~g}$ subsamples, of dried manure material in $15 \mathrm{~mL}$ centrifuge tubes with $10 \mathrm{~mL}$ of $0.25 \mathrm{~mol} \mathrm{~L}^{-1} \mathrm{NaOH}+$ $50 \mathrm{mmol} \mathrm{L}^{-1}$ EDTA (Turner, 2008). The tubes were shaken for $4 \mathrm{~h}$ on an end-over-end shaker at $25^{\circ} \mathrm{C}$. After centrifugation at $2510 \mathrm{RCF}$ (relative centrifugal force) for $15 \mathrm{~min}$, the extract of one subsample was used to estimate total $\mathrm{P}, \mathrm{Ca}, \mathrm{Mg}, \mathrm{Fe}$, and $\mathrm{Al}$ concentration. The extracts of the other four manure subsamples were combined and transferred into $100 \mathrm{~mL}$ snap cap tubes. The extracts were frozen and lyophilized to complete dryness. Subsequently, the lyophilized extract was dissolved in $2.7 \mathrm{~mL}$ of $0.25 \mathrm{~mol} \mathrm{~L}^{-1} \mathrm{NaOH}+50 \mathrm{mmol} \mathrm{L}^{-1}$ EDTA. An amount of $0.3 \mathrm{~mL} \mathrm{D}_{2} \mathrm{O}$ was added and the mixture vortexstirred for $5 \mathrm{~min}$. After $120 \mathrm{~min}$ rest, the supernatant was separated by centrifugation ( $2510 \mathrm{~g}$ for $15 \mathrm{~min}$ ), filtered $(<0.45 \mu \mathrm{m})$ and transferred to $5 \mathrm{~mm}$ NMR tubes (Cade-Menun, 2005). The $\mathrm{P}$ spectra were obtained in a Bruker Advance DPX 400 spectrometer at a frequency of $162 \mathrm{MHz}$ with proton decoupling. A pulse angle of $90^{\circ}$ was used at $20^{\circ} \mathrm{C}$ an acquisition time of 0.2 and 15 s relaxation time (McDowell et al., 2006). The number of scans was 12,000 . The peak area was determined by electronic integration at a baseline of $1 \mathrm{~Hz}$.

The chemical shifts were obtained in relation to $85 \%$ orthophosphoric acid and interpreted, according to Doolette et al. (2009), as follows: orthophosphate (6.2 ppm), pyrophosphate (-4.3 ppm), myo-inositol hexakisphosphate - myo-IHP $(5.9,5.0,4.7$ and $4.6 \mathrm{ppm})$, other monoesters (4.2 to $5.9 \mathrm{ppm})$ and diesters (-0.16 ppm). Software MestRe-C v 2.3a was used for peak area integration.

\section{Statistical analysis}

For the comparison of the $\mathrm{P}$ proportion extracted in each fraction of Chang and Jackson fractionation, and the $\mathrm{P}$ and $\mathrm{Ca}$ desorption kinetic parameters obtained by fitting the McKean and Warren equation, the means of each manure type were compared by the Kruskal-Wallis $H$ test (non-parametric test).

\section{RESULTS AND DISCUSSION}

Total manure $\mathrm{P}$ contents $(11.4,58.1$ and 28.0 $\mathrm{g} \mathrm{kg}^{-1}$ in PM, SM and CM, respectively) are presented in table 2 . In contrast to the total P contents, PM contained most organic $\mathrm{P}\left(4.1 \mathrm{~g} \mathrm{~kg}^{-1}\right)$ whereas both $\mathrm{SM}$ and $\mathrm{CM}$ contained less than $0.1 \mathrm{~g} \mathrm{~kg}^{-1}$. Total $\mathrm{Ca}$ and $\mathrm{Mg}$ contents were also highest in SM. Moreover, higher total $\mathrm{Ca}$ and lower total $\mathrm{Mg}$ was determined in $\mathrm{PM}$ than CM. The ratio of $\mathrm{Ca}$ for $\mathrm{P}$ and $\mathrm{Mg}$ varied significantly and $\mathrm{Ca}: \mathrm{P}$ were $1.3,0.3$ and 0.7 whereas Ca: $\mathrm{Mg}$ were 0.5, 2.2 and 0.9 for PM, CM and SM, respectively. Averaged across all manure types, the 
total Mg:P was $0.65 \pm 0.05$. Total $\mathrm{K}$ and $\mathrm{N}$ did not vary greatly, and their mean contents were 21.5 and $23.3 \mathrm{~g} \mathrm{~kg}^{-1}$, respectively.

Many researchers documented that manure $\mathrm{Ca}$ and $\mathrm{Mg}$ content control P release. Nair et al. (2003) stated that $\mathrm{P}$ release is influenced primarily by $\mathrm{Ca}$ and $\mathrm{Mg}$ concentrations in the manure. The $\mathrm{Mg}$ concentration in the manure could have a detrimental effect on Ca-P stabilization in manure. Our results show that to minimize the environmental impact of manure applications, it is necessary to reduce the manure Mg contents through dietary control or by manure pre-treatment prior to soil application.

The results of chemical fractionation showed the highest proportion of $\mathrm{P}$ extracted with $\mathrm{NH}_{4} \mathrm{Cl}$ in $\mathrm{PM}$ followed by CM and then SM (Table 2). The two first extractants from this fractionation $\left(1.0 \mathrm{~mol} \mathrm{~L}^{-1} \mathrm{NH}_{4} \mathrm{Cl}\right.$ and $0.5 \mathrm{~mol} \mathrm{~L}^{-1} \mathrm{NH}_{4} \mathrm{~F} \mathrm{pH} 8.2$ extracted an approximate mean of $90 \%$ of the total $\mathrm{P}$ for all manure types. On average, the proportion of $\mathrm{P}$ extracted by $0.25 \mathrm{~mol} \mathrm{~L}^{-1}$

Table 2. Selected chemical characteristics, sequential chemical $P$ fractionation, $P$ and Ca desorption kinetic parameters and organic $P$ molecular species determined by ${ }^{31} \mathbf{P}$ nuclear magnetic resonance spectroscopy in three manure types

\begin{tabular}{|c|c|c|c|c|c|c|}
\hline \multirow{2}{*}{ Variable } & \multicolumn{6}{|c|}{ Manure } \\
\hline & \multicolumn{2}{|c|}{ Poultry } & \multicolumn{2}{|c|}{ Cattle } & \multicolumn{2}{|c|}{ Swine } \\
\hline Total element concentration & \multicolumn{2}{|c|}{$\mathrm{g} \mathrm{kg}^{-1}$} & \multicolumn{2}{|c|}{$\mathrm{g} \mathrm{kg}^{-1}$} & \multicolumn{2}{|c|}{$\mathrm{g} \mathrm{kg}^{-1}$} \\
\hline $\mathrm{P}$ & \multicolumn{2}{|c|}{$11.4 \pm 0.3$} & \multicolumn{2}{|c|}{$28.0 \pm 1.1$} & \multicolumn{2}{|c|}{$58.1 \pm 2.9$} \\
\hline $\mathrm{Ca}$ & \multicolumn{2}{|c|}{$14.9 \pm 1.4$} & \multicolumn{2}{|c|}{$8.9 \pm 0.5$} & \multicolumn{2}{|c|}{$39.3 \pm 0.9$} \\
\hline $\mathrm{Mg}$ & \multicolumn{2}{|c|}{$7.0 \pm 0.3$} & \multicolumn{2}{|c|}{$19.9 \pm 0.7$} & \multicolumn{2}{|c|}{$36.1 \pm 0.5$} \\
\hline $\mathrm{K}$ & \multicolumn{2}{|c|}{$24.2 \pm 0.4$} & \multicolumn{2}{|c|}{$18.2 \pm 0.4$} & \multicolumn{2}{|c|}{$22.1 \pm 0.7$} \\
\hline $\mathrm{N}$ & \multicolumn{2}{|c|}{$18.7 \pm 0.5$} & \multicolumn{2}{|c|}{$29.3 \pm 0.8$} & \multicolumn{2}{|c|}{$21.9 \pm 1.3$} \\
\hline Organic P & \multicolumn{2}{|c|}{$4.1 \pm 0.8$} & \multicolumn{2}{|c|}{$<0.1$} & \multicolumn{2}{|c|}{$<0.1$} \\
\hline $\mathrm{P}$ chemical fractionation & $\mathrm{mg} \mathrm{kg}^{-1}$ & $\%$ & $\mathrm{mg} \mathrm{kg}^{-1}$ & $\%$ & $\mathrm{mg} \mathrm{kg}^{-1}$ & $\%$ \\
\hline $1.0 \mathrm{~mol} \mathrm{~L}^{-1} \mathrm{NH}_{4} \mathrm{Cl}$ & $8976 \pm 438$ & $78.0 \mathrm{a}$ & $19184 \pm 464$ & $64.1 \mathrm{~b}$ & $31610 \pm 852$ & $57.8 \mathrm{c}$ \\
\hline $0.5 \mathrm{~mol} \mathrm{~L}^{-1} \mathrm{NH}_{4} \mathrm{~F} \mathrm{pH} 8.2$ & $1217 \pm 184$ & $10.6 \mathrm{~b}$ & $8930 \pm 339$ & $29.8 \mathrm{a}$ & $18138 \pm 696$ & $33.2 \mathrm{a}$ \\
\hline $0.1 \mathrm{~mol} \mathrm{~L}^{-1} \mathrm{NaOH}$ & $293 \pm 25$ & $2.5 \mathrm{~b}$ & $1250 \pm 51$ & $4.1 \mathrm{a}$ & $410 \pm 85$ & $0.7 \mathrm{c}$ \\
\hline CBD & $20 \pm 11$ & $0.2 \mathrm{a}$ & $39 \pm 22$ & $0.1 \mathrm{a}$ & $111 \pm 11$ & $0.2 \mathrm{a}$ \\
\hline $0.25 \mathrm{~mol} \mathrm{~L}^{-1} \mathrm{H}_{2} \mathrm{SO}_{4}$ & $915 \pm 223$ & $7.9 \mathrm{a}$ & $227 \pm 22$ & $0.7 \mathrm{~b}$ & $4282 \pm 569$ & $7.9 \mathrm{a}$ \\
\hline Residual & $139 \pm 26$ & $1.2 \mathrm{a}$ & $290 \pm 37$ & $0.9 \mathrm{a}$ & $128 \pm 6$ & $0.2 \mathrm{~b}$ \\
\hline $\mathrm{P}$ desorption parameter & $\mathrm{g} \mathrm{kg}^{-1}$ & $\%$ & $\mathrm{~g} \mathrm{~kg}^{-1}$ & $\%$ & $\mathrm{~g} \mathrm{~kg}^{-1}$ & $\%$ \\
\hline$\alpha-P$ & $3.78 \pm 0.8$ & $33.1 \mathrm{a}$ & $9.2 \pm 1.6$ & $32.8 \mathrm{a}$ & $11.4 \pm 1.2$ & $19.6 \mathrm{~b}$ \\
\hline$\beta-P$ & $10.1 \pm 0.7$ & $88.6 \mathrm{~b}$ & $27.1 \pm 1.6$ & $96.9 \mathrm{a}$ & $52.1 \pm 3.2$ & $89.6 \mathrm{~b}$ \\
\hline$\lambda-\mathrm{P}^{*}$ & $0.033 \pm 0.003 \mathrm{a}$ & - & $0.033 \pm 0.003 \mathrm{a}$ & - & $0.016 \pm 0.001 \mathrm{~b}$ & - \\
\hline Ca desorption parameter & $\mathrm{g} \mathrm{kg}^{-1}$ & $\%$ & $\mathrm{~g} \mathrm{~kg}^{-1}$ & $\%$ & $\mathrm{~g} \mathrm{~kg}^{-1}$ & $\%$ \\
\hline$\alpha-\mathrm{Ca}$ & $3.2 \pm 0.7$ & $24 \mathrm{a}$ & $2.2 \pm 0.3$ & $21 \mathrm{a}$ & $1.7 \pm 0.2$ & $5 \mathrm{~b}$ \\
\hline$\beta-\mathrm{Ca}$ & $13.5 \pm 1.0$ & $100 \mathrm{a}$ & $10.9 \pm 1.0$ & $103 \mathrm{a}$ & $37.3 \pm 0.8$ & $112 \mathrm{a}$ \\
\hline$\lambda-\mathrm{Ca}^{*}$ & $0.015 \pm 0.001 \mathrm{a}$ & - & $0.012 \pm 0.002 \mathrm{a}$ & - & $0.007 \pm 0.001 \mathrm{~b}$ & - \\
\hline $\mathrm{NaOH}+\mathrm{EDTA}$ extraction & $\mathrm{mg} \mathrm{kg}^{-1}$ & $\%$ & $\mathrm{mg} \mathrm{kg}{ }^{-1}$ & $\%$ & $\mathrm{mg} \mathrm{kg}{ }^{-1}$ & $\%$ \\
\hline $\mathrm{P}$ & $11872 \pm 587$ & 104 & $31520 \pm 371$ & 113 & $59533 \pm 399$ & 102 \\
\hline $\mathrm{Ca}$ & $339 \pm 12$ & 2.3 & $178 \pm 15$ & 2.0 & $960 \pm 32$ & 2.4 \\
\hline $\mathrm{Mg}$ & $106 \pm 5$ & 1.5 & $247 \pm 11$ & 1.2 & $323 \pm 3$ & 0.9 \\
\hline $\mathrm{Fe}$ & $603 \pm 24$ & - & $259 \pm 24$ & - & $120 \pm 11$ & - \\
\hline $\mathrm{Al}$ & $142 \pm 15$ & - & 0 & - & 0 & - \\
\hline $\mathrm{P}$ speciation by ${ }^{31} \mathrm{P}-\mathrm{NMR}$ & $\mathrm{mg} \mathrm{kg}^{-1}$ & $\%$ & $\mathrm{mg} \mathrm{kg}^{-1}$ & $\%$ & $\mathrm{mg} \mathrm{kg}^{-1}$ & $\%$ \\
\hline Orthophosphate & 11102 & 93.3 & 31815 & 99.4 & 62523 & 99.1 \\
\hline Pyrophosphate & 52 & 0.4 & 56 & 0.2 & 181 & 0.3 \\
\hline Total inorganic P & 11154 & 93.7 & 31871 & 99.6 & 62705 & 99.4 \\
\hline Myo-IHP & 539 & 4.5 & 0.0 & 0.0 & 0 & 0.0 \\
\hline Others monoesters & 185 & 1.6 & 129 & 0.4 & 395 & 0.6 \\
\hline Diesters & 22 & 0.2 & 0.0 & 0.0 & 0 & 0.0 \\
\hline Total organic $\mathrm{P}$ & 746 & 6.3 & 129 & 0.4 & 395 & 0.6 \\
\hline
\end{tabular}

Means followed by the same letter in a row comparing different manure types are not different by the Kruskal-Wallis $\mathrm{H}$ test at $\mathrm{p}<0.05$.

* Values are in $\mathrm{g} \mathrm{kg}^{-1} \mathrm{~h}^{-1}$. 
$\mathrm{H}_{2} \mathrm{SO}_{4}$ was $7.9 \%$ in $\mathrm{PM}$ and $\mathrm{SM}$, while only $0.7 \%$ in $\mathrm{CM}$. The other extractants of the Chang and Jackson method extracted very low amounts of $P$.

The readily bioavailable proportions of $\mathrm{P}$ and $\mathrm{Ca}$ $(\alpha-\mathrm{P}$ and $\alpha-\mathrm{Ca})$, determined with successive anioncation exchange resin release kinetics were $33.0 \%$ higher in PM and $22.5 \%$ in $\mathrm{CM}$, respectively) than in SM which was 19.6 and $5.0 \%$, respectively (Table 2). However, potentially available P ( $\beta-\mathrm{P})$ was higher in CM (96.9\%) than in PM and SM (89.1\%). Thus, $\alpha-\mathrm{P}$ represents only $37.4,33.9$ and $21.9 \%$ of $\beta$-P in PM, CM and SM, respectively. Desorption constants of $\mathrm{P}(\lambda-\mathrm{P})$ and $\mathrm{Ca}(\lambda-\mathrm{Ca})$ in $\mathrm{SM}$ was 0.016 and 0.007 $\mathrm{mg} \mathrm{kg}{ }^{-1} \mathrm{~h}^{-1}$, respectively. This concentration is approximately half of that in PM and CM (0.033 and $0.0135 \mathrm{mg} \mathrm{kg}^{-1} \mathrm{~h}^{-1}$, respectively). The desorption proportions of PM and CM were similar for $\mathrm{P}$ and $\mathrm{Ca}$ until the third extraction, However, from then on until the end, PM was close to SM proportions (Figure 1).

The results for $\mathrm{CM}$ indicated that the higher proportion of $\mathrm{P}$ labile forms ( $\mathrm{sum}$ of $\mathrm{NH}_{4} \mathrm{Cl}$ and $\mathrm{NH}_{4} \mathrm{~F}$ ), and potentially bioavailable $\mathrm{P}(\beta-\mathrm{P})$, compared to the other manure types typically show higher total $\mathrm{Mg}: \mathrm{Ca}$
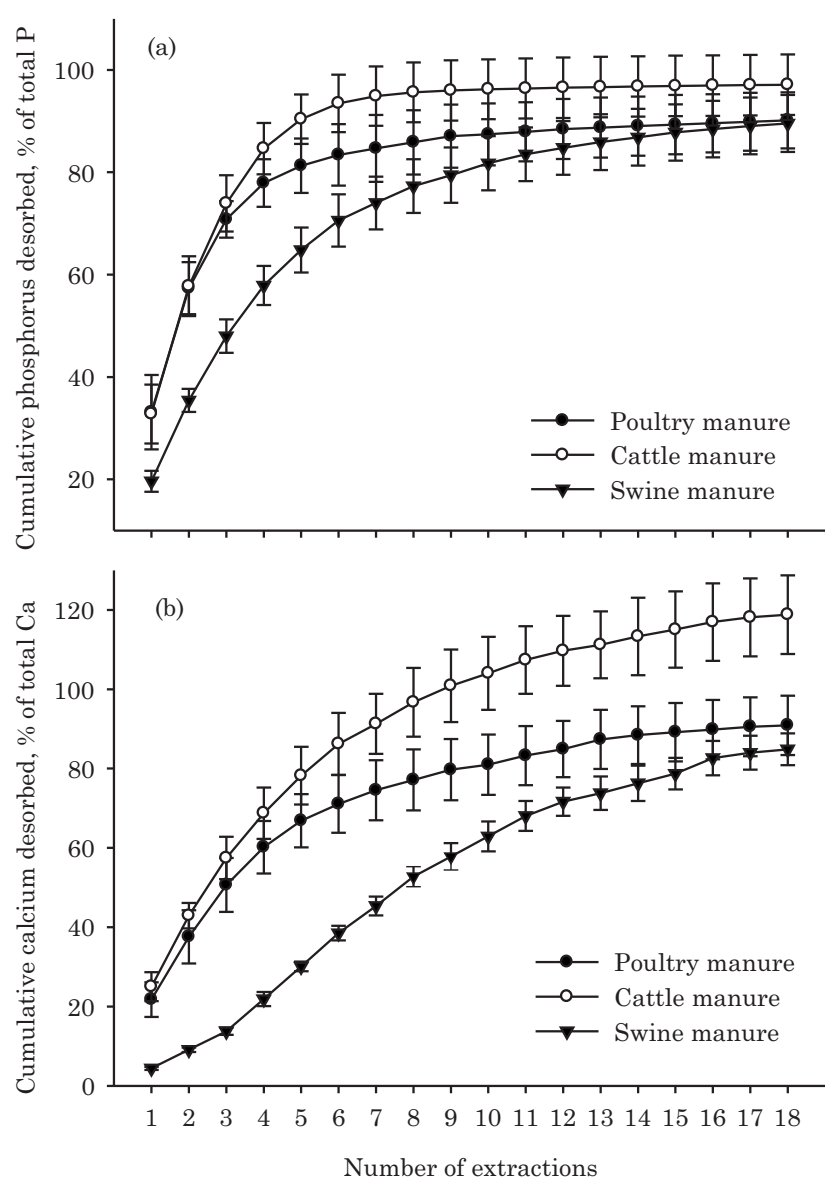

Figure 1. Cumulative phosphorus (a) and calcium (b) desorbed by successive anion-cation exchange resin extractions in poultry, cattle, and swine manure. and lower total Ca:P ratios. In addition, the lowest total Ca: $\mathrm{P}$ ratio in $\mathrm{CM}$ also explains the lowest proportion of $\mathrm{P}$ extracted by $\mathrm{H}_{2} \mathrm{SO}_{4}$, which is considered as $\mathrm{P}$ bonded to $\mathrm{Ca}$ in the Chang and Jackson fractionation. On the other hand, in PM and SM there was a higher proportion of $\mathrm{P}$ bound to Ca than in $\mathrm{CM}$, as evidenced both by the higher total $\mathrm{Ca}: \mathrm{P}$ ratio and the higher proportion of $\mathrm{P}$ extracted by $\mathrm{H}_{2} \mathrm{SO}_{4}$. Furthermore, the $\mathrm{P}$ proportion not desorbed from all manure types after the successive extractions with resins (total $\mathrm{P}$ minus $\beta-\mathrm{P}$ ) was very close to the $\mathrm{P}$ amount bonded to Ca estimated by the extraction with $\mathrm{H}_{2} \mathrm{SO}_{4}$. Therefore, this indicates that P-Ca linkage decreases $\mathrm{P}$ availability. In this regard, when the total $\mathrm{Ca}: \mathrm{P}$ ratio is higher, there is a net transformation of more soluble (dicalcium phosphate) to less soluble $\mathrm{P}$ compounds (hydroxylapatite) as reported by Toor et al. (2005), which decreases the potential of $\mathrm{P}$ transfer to water.

The extraction with $\mathrm{NaOH}+$ EDTA for ${ }^{31} \mathrm{P}-\mathrm{NMR}$ spectroscopy analysis was sufficient to extract almost all $\mathrm{P}$ from the manures (Table 2). The $\mathrm{NaOH}+$ EDTA extracts contained low concentration of paramagnetic metals $(\mathrm{Ca}, \mathrm{Mg}, \mathrm{Fe}$, and $\mathrm{Al}$ ) that can interfere with the quality of signal acquisition of the nuclear magnetic resonance spectra. This indicates that the spectra obtained are true representatives of $\mathrm{P}$ forms existing in each manure without interference of paramagnetic ions (Cade-Menun, 2005).

In all manure types, the principal $\mathrm{P}$ form detected by ${ }^{31} \mathrm{P}-\mathrm{NMR}$ was inorganic $\mathrm{P}$, almost entirely in the orthophosphate form at $\delta=6.2 \mathrm{ppm}$ (on average $99.7 \%$ of the inorganic fraction) and the rest in the pyrophosphate form at $\delta=-4.3 \mathrm{ppm}$ (Table 2). The organic $\mathrm{P}$ in $\mathrm{CM}$ and $\mathrm{SM}$ was 0.4 and $0.6 \%$, respectively mainly in the form of phosphate monoester $(\delta=5.9$ to $\delta=4.2 \mathrm{ppm})$. However, in PM the proportion of organic $\mathrm{P}$ was $6.3 \%$ and only $0.2 \%$ in the diester form of DNA $(\delta=-0.16 \mathrm{ppm})$ and the rest in monoester form. In this analysis, no spike was used in the samples with known organic $\mathrm{P}$ compounds as recommended by Doolette et al. (2009). However, in the monoester organic $\mathrm{P}$ region, it was possible to clearly identify $m y_{o}$-inositol hexakisphosphate in PM (Myo-IHP) by the chemical shifts at $\delta=5.9,5.0,4.7$, and 4.6 (Figure 2). Phytate (Myo-IHP) was the main organic form found in PM, reaching $72 \%$ of the organic $\mathrm{P}$.

Our results are in agreement with those of $\mathrm{He}$ et al. (2007) and Leytem et al. (2008b), who characterized $\mathrm{P}$ compounds in poultry and dairy manures by solution ${ }^{31} \mathrm{P}-\mathrm{NMR}$ in $\mathrm{NaOH}+$ EDTA extracts. They found that in dairy manure, inorganic $\mathrm{P}$ was the major $\mathrm{P}$ fraction (64-73\%), followed by $6 \%$ phytic acid, 14 to $22 \%$ other monoesters, and $7 \%$ phosphodiesters, whereas in the poultry manure, results showed that orthophosphate accounted for 51 to $63 \%$, phytic acid 24 to $33 \%$, other phosphomonoesters 6 to $12 \%$, and phospholipids and DNA $2 \%$ each. McDowell \& Stewart (2005) also separated manure $\mathrm{P}$ forms in fresh and 


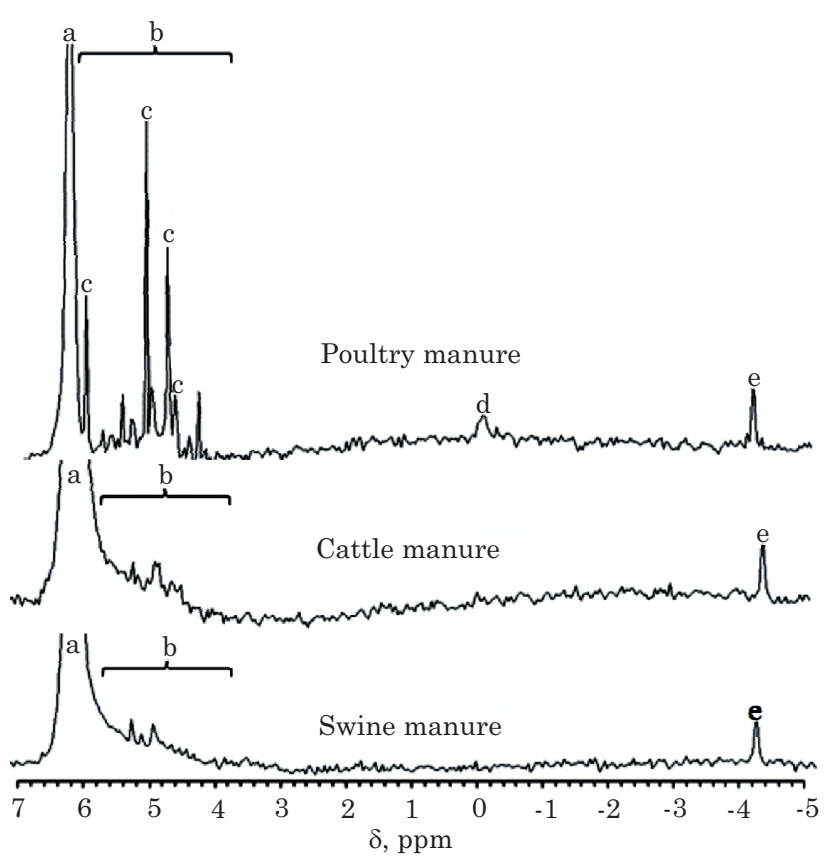

Figure 2. Solution ${ }^{31} \mathrm{P}$ nuclear magnetic resonance spectra of poultry, cattle, and swine manure. The letters indicate the $P$ form as follow: $a=$ orthophosphate, $\mathbf{b}=$ monoester phosphates, $\mathbf{c}=$ Myo-inositol hexakisphosphate (phytate), $\mathrm{d}=$ diester phosphate (DNA), and e = pyrophosphate.

air-dried dung of animals (dairy cattle, deer, sheep) by ${ }^{31} \mathrm{P}-\mathrm{NMR}$. The ${ }^{31} \mathrm{P}-\mathrm{NMR}$ data showed that changes in organic $\mathrm{P}$ concentration with drying can be attributed to degradation of diesters. This may explain the low concentration of organic $\mathrm{P}$ assessed by ${ }^{31} \mathrm{P}-\mathrm{NMR}$ in our manure samples, especially in the diester fraction. However, our organic $\mathrm{P}$ results obtained with ${ }^{31} \mathrm{P}-\mathrm{NMR}$ spectroscopy were consistent with those estimated by the ignition method. Although CM and SM represented minor amounts of organic P, PM contained s considerable proportion, mainly in the form of phytate $\mathrm{P}(\mathrm{PP})$.

According to Tamim et al. (2004) and Leytem et al. (2008a), supplemental minerals, such as $\mathrm{Ca}$ and other divalent and trivalent cations can form stable complexes with phytate and result in reduced PP hydrolysis. The ability to hydrolyze PP by phytase may be reduced at greater concentrations of Ca because of increased $\mathrm{pH}$ in the intestine and an increase in Ca-PP salt formation (Manangi \& Coon, 2008). The Ca-PP complexes are only soluble at low $\mathrm{pH}$ values or in the presence of strong complexing agents such as EDTA (Seaman et al., 2003; Turner, 2004). Thus, based on the combined analysis of the proportion of $\mathrm{P}$ extracted with $\mathrm{H}_{2} \mathrm{SO}_{4}$ by the Chang and Jackson fractionation and the higher proportion of PP (MyoIHP) obtained by ${ }^{31} \mathrm{P}-\mathrm{NMR}$ spectroscopy, we can infer that most of the $\mathrm{P}$ bonded to Ca in PM was possibly Ca chelated by phytate, or an organic mineral complex with Ca-PP (Table 2).
Aside from this low availability fraction, the lability of the remainder P present in PM was high, similar to $\mathrm{CM}$ as indicated by the high proportion of $\alpha-\mathrm{P}, \alpha-\mathrm{Ca}$ and the higher $\lambda-\mathrm{P}$ and $\lambda$-Ca, and the higher proportion of $\mathrm{P}$ extracted by $\mathrm{NH}_{4} \mathrm{Cl}$ in both $\mathrm{PM}$ and CM. On the other hand, SM showed no PP and although its $\mathrm{Ca}: \mathrm{P}$ ratio was approximately half that of PM, most of the $\mathrm{Ca}$ in this manure probably formed low solubility inorganic complexes with $\mathrm{P}$ e.g., hydroxylapatite (Toor et al., 2005).This also explains the lower proportion of $\alpha-\mathrm{P}$ and $\alpha$ - $\mathrm{Ca}$ in $\mathrm{SM}$, lower $\lambda$-P and $\lambda-\mathrm{Ca}$ and also the lower $\mathrm{P}$ proportion extracted by $\mathrm{NH}_{4} \mathrm{Cl}$.

The discussion and the interactions pointed out above show that the results obtained by sequential chemical fractionation of $\mathrm{P}$, successive extraction with resins and ${ }^{31} \mathrm{P}-\mathrm{NMR}$ spectroscopy allowed a complete characterization of the manure $\mathrm{P}$ and further indicated that the inorganic $\mathrm{P}$ fraction is predominant in all three manure types and is highly bioavailable (Table 2). Consequently, manure surface application under NT may increase the potential for soluble inorganic $\mathrm{P}$ loss in surface runoff at increased rates if the manure contribution to the available $\mathrm{P}$ pool is not taken into account for crops already fertilized with manure, as recommended by the CQFSRS/SC (2004). In this way, successive and long-term manure applications need to be controlled to avoid excessive amendments and consequent environmental problems, especially those related with $\mathrm{P}$ leaching to surface and groundwater.

\section{CONCLUSIONS}

1. The sequential chemical fractionation of $P$, the successive extraction with resins and the ${ }^{31} \mathrm{P}-\mathrm{NMR}$ spectroscopy methods showed that the $\mathrm{P}$ forms in poultry, cattle and swine dry manures are mostly inorganic and highly bioavailable.

2. The organic and recalcitrant $P$ forms were negligible and are highly dependent on the $\mathrm{Ca}: \mathrm{P}$ ratio in manures.

3 . The results obtained here show that the three different methods, when applied together, allow a complete characterization of the $\mathrm{P}$ present in manures.

\section{LITERATURE CITED}

AZEEZ, J.O. \& AVERBEKE, W.V. Fate of manure phosphorus in a weathered sandy clay loam soil amended with three animal manures. Bioresour. Technol., 101:6584-6588, 2010.

CADE-MENUN, B.J. Using phosphorus-31 nuclear magnetic resonance spectroscopy to characterize organic phosphorus in environmental samples. In: TURNER, B.L.; FROSSARD, E. \& BALDWIN, D.S., eds. Organic phosphorus in the environmental. Wallingford, CAB International, 2005. p.21-44. 
CHANG, S.C. \& JACKSON, M.L. Fractionation of soil phosphorus. Soil Sci., 84:133-144, 1957.

CORDELL, D.; DRANGERT, J.O. \& WHITE, S. The story of phosphorus: Global food security and food for thought. Global Environ. Change, 19:292-305, 2009.

CORDELL, D.; ROSEMARIN, A.; SCHRÖDER, J.J. \& ESIT, A.L. Towards global phosphorus security: A systems framework for phosphorus recovery and reuse options. Chemosphere, 84:747-758, 2011.

COMISSÃO DE QUÍMICA E FERTILIDADE DO SOLO CQFSRS/SC. Manual de adubação e calagem para os estados do Rio Grande do Sul e Santa Catarina. 10.ed. Porto Alegre, 2004. 400p.

DAWSON, C. \& HILTON, J. Fertilizer availability in a resourcelimited world: Production and recycling of nitrogen and phosphorus. Food Policy, 36:14-22, 2011.

DOOLETTE, A.L.; SMERNIK, R.J. \& DOUGHERTY, W.J. Spiking improved solution pho sphorus-31 nuclear magnetic resonance identification of soil phosphorus compounds. Soil Sci. Soc. Am. J., 73:919-927, 2009.

DOU, Z.; TOTH, J.D.; GALLIGAN, D.T.; RAMBERG, C.F. \& FERGUSON, J.D. Laboratory procedures for characterizing manure phosphorus. J. Environ. Qual., 29:508-514, 2000.

GILBERT, N. The disappearing nutrient. Nature, 461:716$718,2009$.

GUARDINI, R.; COMIN, J.J.; SCHMITT, D.E.; TIECHER, T.; BENDER, M.A.; RHEINHEIMER, D.S.; MEZZARI, C.P.; OLIVEIRA, B.S.; GATIBONI, L.C. \& BRUNETTO, G. Accumulation of phosphorus fractions in typic Hapludalf soil after long-term application of pig slurry and deep pig litter in a no-tillage system. Nutr. Cycl. Agroecosyst., 93:215-225, 2012.

HALAJNIA, A.; HAGHNIA, G.H.; FOTOVAT, A. \& KHORASANI, R. Phosphorus fractions in calcareous soils amended with $\mathrm{P}$ fertilizer and cattle manure. Geoderma, 150:209-213, 2009.

HE, Z.; CADE-MENUN, B.J.; TOOR, G.S.; FORTUNA, A.M.; HONEYCUTT, C.W. \& SIMS, T. Comparison of phosphorus forms in wet and dried animal manures by solution phosphorus-31 nuclear magnetic resonance spectroscopy and enzymatic hydrolysis. J. Environ. Qual., 36:1086-1095, 2007.

INSTITUTO BRASILEIRO DE GEOGRAFIA E ESTATÍSTICA - IBGE. 2010. Available at: <http://www.ibge.gov.br/home/ >. Accessed on: Dec. 16, 2010.

INTERNATIONAL FERTILIZER INDUSTRY ASSOCIATION - IFA. 2013. Available at: <http://www.fertilizer.org/ifa/ ifadata/results>. Accessed on: Aug. 20, 2013.

KING, K.W.; BALOGH, J.C.; AGRAWAL, S.G.; TRITABAUGH, C.J. \& RYAN, J.A. Phosphorus concentration and loading reductions following changes in fertilizer application and formulation on managed turf. J. Environ. Monit., 14:29292938, 2012.
LEYTEM, A.B.; MIKKELSEN, R.L. \& GILLIAM, J.W. Sorption of organic phosphorus compounds in Atlantic coastal plain soils. Soil Sci., 167:652-658, 2002.

LEYTEM, A.B.; KWANYUEN, R.; PLUMSTEAD, P.W.; MAGUIRE, R.O. \& BRAKE, J. Evaluation of phosphorus characterization in broiler heal digesta, manure, and litter samples: ${ }^{31}$ P-NMR vs. HPLC. J. Environ. Qual., 37:494500, 2008a.

LEYTEM, A.B.; PLUMSTEAD, P.W.; MAGUIRE, R.O.; KWANYUEN, P.; BURTON, J.W. \& BRAKE, J. Interaction of calcium and phytate in broiler diets. 2 . Effects on total and soluble phosphorus excretion. Poultry Sci., 87:459-467, 2008b.

MANANGI, M.K. \& COON, C.N. Phytate phosphorus hydrolysis in broilers in response to dietary phytase, calcium, and phosphorus concentrations. Poultry Sci., 87:1577-1586, 2008.

McDOWELL, R.; SHARPLEY, A. \& KLEINMAN, P. Surface water quality and phosphorus applications. Encycl. Water Sci., 1:961-964, 2003.

McDOWELL, R.W. \& STEWART, I. Phosphorus in fresh and dry dung of grazing dairy cattle, deer and sheep: Sequential fractionation and phosphorus-31 nuclear magnetic resonance analysis. J. Environ. Qual., 34:598607, 2005.

McDOWELL, R.W.; STEWART, I. \& CADE-MENUN, B.J. An examination of spin-lattice relaxation times for analysis of soil and manure extracts by liquid state phosphorus-31 nuclear magnetic resonance spectroscopy. J. Environ. Qual., 35:293-302, 2006.

McKEAN, S.J. \& WARREN, G.P. Determination of phosphate desorption characteristics in soils using successive resin extractions. Commun. Soil Sci. Plant Anal., 27:2397-2417, 1996.

MURPHY, J. \& RILEY, J.P. A modified single solution method for the determination of phosphate in natural waters. Anal. Chim. Acta, 27:31-36, 1962.

NAIR, V.D.; GRAETZ, D.A. \& DOOLEY, D.O. Phosphorus release characteristics of manure and manure-impacted soils. Food Agric. Environ., 1:217-223, 2003.

NASH, D.; HANNAH, M.; BARLOW, K.; ROBERTSON, F.; MATHERS, N.; BUTLER, C. \& HORTON, J. A comparison of some surface soil phosphorus tests that could be used to assess P export potential. Aust. J. Soil Res., 45:397-400, 2007.

OLSEN, S.R. \& SOMMERS, L.E. Phosphorus. In: PAGE, A.L.; MILLER, R.H. \& KEENEY, D.R., eds. Methods of soil analysis. Madison, American Society of Agronomy, 1982. Part 2. p.403-430.

RUSSELL, M.J.; WELLER, D.E.; JORDAN, T.E.; SIGWART, K.J. \& SULLIVAN, K.J. Net anthropogenic phosphorus inputs:spatial and temporal variability in the Chesapeake Bay region. Biogeochemistry, 88:285-304, 2008.

SEAMAN, J.C.; HUTCHISON, J.M.; JACKSON, B.P. \& VULAVA, V.M. In situ treatment of metals in contaminated soils with phytate. J. Environ. Qual., 32:153-161, 2003. 
SHAFQAT, M.N. \& PIERZYNSKI, G.M. Soil test phosphorus dynamics in animal waste amended soils: using $\mathrm{P}$ mass balance approach. Chemosphere, 90:691-698, 2013.

SHARPLEY, A. \& MOYER, B. Phosphorus forms in manure and compost and their release during simulated rainfall. J. Environ. Qual., 29:1462-1469, 2000.

SHARPLEY, A.N.; McDOWELL, R.W. \& KLEINMAN, P.J.A. Amounts, forms, and solubility of phosphorus in soils receiving manure. Soil Sci. Soc. Am. J., 68:2048-2057, 2004.

SHEN, J.; YUAN, L.; ZHANG, J.; LI, H.; BAI, Z.; CHEN, X.; ZHANG, W. \& ZHANG, F. Phosphorus dynamics: From soil to plant. Plant Physiol., 156:997-1005, 2011.

TAMIM, N.M.; ANGEL, R. \& CHRISTMAN, M. Influence of dietary calcium and phytase on phytate phosphorus hydrolyses in broiler chickens. Poultry Sci., 83:1358-1367, 2004.

TEDESCO, M.J.; GIANELLO, C.; BISSANI, C.A.; BOHNEN, H. \& VOLKWEISS, S.J. Análises de solo, planta e outros materiais. 2.ed. Porto Alegre, Universidade Federal do Rio Grande do Sul, 1995. 174p.
TOOR, G.S.; CONDRON, L.M.; DI, H.J.; CAMERON, K.C. \& CADE-MENUN, B.J. Characterization of organic phosphorus in leachate from a grassland soil. Soil Biol. Biochem., 35:1317-1323, 2003.

TOOR, G.S.; CONDRON, L.M.; DI, H.J. \& CAMERON, K.C. Seasonal fluctuations in phosphorus loss by leaching from a grassland soil. Soil Sci. Soc. Am. J., 68:1429-1436, 2004.

TOOR, G.S.; PEAK, J.D. \& SIMS, J.T. Phosphorus speciation in broiler litter and turkey manure produced from modified diets. J. Environ. Qual., 34:687-697, 2005.

TURNER, B.L. Optimizing phosphorus characterization in animal manures by phosphorus-31 nuclear magnetic resonance spectroscopy. J. Environ. Qual., 33:757-766, 2004.

TURNER, B.L. Soil organic phosphorus in tropical forests: An assessment of the $\mathrm{NaOH}$-EDTA extraction procedure for quantitative analysis by solution ${ }^{31} \mathrm{P}$ NMR spectroscopy. Eur. J. Soil Sci., 59:453-466, 2008.

UNITED STATES ENVIRONMENTAL PROTECTION AGENCY - USEPA. Methods of chemical analysis for water and wastes. Cincinnati, US. Environmental Protection Agency, 1971. 